\title{
Analysis of relationship between language applications and culture; Angkola- Mandailing community
}

\author{
Anna Leli Harahap \\ English Department, Faculty of Teaching and Training, Universitas Al \\ Washliyah Labuhanbatu \\ Correspondence : annaleliharahap25@gmail.com
}

\begin{abstract}
This research discussed about the relationship between language application and culture; language as a means of culture in AngkolaMandailing community, and this research intended to know the relationship between language application and culture in Angkola Angkola- Mandailing community. This research was conducted by qualitative-descriptive method that describes the relationship between language application and culture based on Nababan's theory (Nababan, 1986). The results of this research are that the relationship between language and culture in Angkola ethnic: 1) language as a means of cultural development; for example margondang, mangayun. 2) Language as a pathway for cultural heir; for example: martahi /marpege-pege, makkobar. 3) And language as an inventory of cultural characteristics; markusip which is no longer practiced by young people in Padangsidimpuan, however, in Angkola- Mandailing community knows what that (markusip). So the relationship between language and culture is very clear in this research, because without language it is culture, and culture includes language.
\end{abstract}

Keywords: Language Applications and Culture; development, heir, inventory

\section{Introduction}

Language is a sign system that is related to the symbol of sounds used by members of a society to communicate and interact with each other based on their culture (Dardjowidjojo, 2003). Whereas culture is whole habit of a group of people that is reflected in the knowledge, actions and results of their work that are used to understand their environment and become a code of conduct for their welfare (Koentjaraningrat, 1992). Language is not only a study of language and culture, but ultimately on the world of relations and influence (Sapir, 1921). He states that the history between language and culture has parallel lines. 
Furthermore, it is said that language determines one's mindset. That's opinion support by (Herman, 2009).

In everyday life, among people who are accustomed to speaking politely, people will immediately judge that the person is virtuous. People who speak intellectually and regularly, then that person is judged as educated, educated and knowledgeable. That's how people judge others by the way they speak. Mustapha Abdallah Bouchouk (Thohiry, 2017) even argues that culture is a language itself. This departs from the assumption that learning a language by itself is studying the culture in which the language is spoken. In studying Arabic, for example he will study how the cultural norms and values adopted by Arabs are different from Indonesians; openness, straightforwardness, straightforward without further ado. Meanwhile, many experts argue that language is subordinator to culture, where language is under culture. This opinion appears that language is a product of culture. This will also cause a long debate, because it seems as if language is influenced by a developing culture. Because on the other hand, there is an opinion that language and culture are coordinative as stated by Sapir and Worf(Sapir, 1921).

Language is a sign system that is related to the symbols of sounds used by certain groups (Barber, 1964). According to Kridalaksana (Kridalaksana, 2008), language is an arbitrary symbol symbol used by a society to cooperate, interact and identify them. Meanwhile, according to Keraf (Keraf, 1984) language is a means of communicating between community members in the form of sounds produced by human speech tools. Culture is the whole habit of community groups that is reflected in their knowledge, actions, and work as social creatures that are used to understand their environment and serve as a guideline for their behavior to achieve peace and welfare of their lives (Sibarani, 2004).

The relationship between language and culture is that language has all the characteristics of culture, because language belongs to members of society, language is reflected in ideas, actions and human works (Chaer, 1995). Language becomes a human means to play a role, act, interact, which functions in people's lives (Sibarani, 1992). Several theses stated about the relationship between language and culture, including; (1) That the growth of a culture will not be complete without language as the main communication tool and the guardian of the culture itself, (2) That language is a form of culture itself (3) Thus, language plays an important role in the formation of society.

Language as a cultural tool is also widely discussed, for example by Samsuri (Samsuri, 1974) who maps the use of language as a cultural instrument in four fields, namely language and literature, language and politics, language and science, language and development. Meanwhile, Levi Strauss in (Darsita, 2003), explained that language and culture have a relationship and differentiate culture in three ways, namely; (1) The language used by the community is considered a reflection of the totality of the culture of the community concerned, (2) Language 
is part of culture, or one of the elements of culture (3) Language is a condition for culture.

Then Darsita (Darsita, 2003) explained the third point, that language is a condition for culture into two things, namely; first, language is a cultural condition in a diachronic sense, where language precedes culture. Because through language, humans become cultured and civilized social beings. Second, language is a condition for culture because the materials used to build language are basically the same material for building culture, in the sense that language is the foundation for the formation of various kinds of complex structures that are parallel to other cultural elements. Thus it becomes clear that language does show how a community or nation is cultured. Between language and culture shows a reciprocal relationship. To maintain culture, language has become a norm. Likewise, to maintain language, cultural sustainability is very important even though culture is the instinct of human life itself as a social being.

Language is a product that is a package, where the human existence is a package with the language used. So language is software that becomes one with the creation of humans. While many orthodox scholars consider language only one of the cultural pillars that are not important. However, it cannot be denied that human civilization has been advancing until now and cannot be separated from language as a means of communication. This communication will transform ideas, ideas, and imagination as well as human reflection into something that develops from time to time towards the direction of perfection. This is marked by the direction of technology development. Communication has become a symbol of the progress of today's civilization with its various technological achievements (McLuhan, 1964). This extends to all walks of life. Even giant business relies on the continuity of its business in the languages that the corporation should know for example, promotion and strengthening of the consumer base. This also marks the role of language in the economic sphere. Whatever the debate occurs regarding each other's position (language and culture), the thesis that there is a close influence between language and culture is very relevant to be discussed. Zaki Hasimuddin (Hassamudin, 2001) emphasized that to see cultural symptoms, it can be seen from several elements that make up the cultural system, including this language. As has been stated above, how can an intellectual person in language compare with street thugs in speaking. Likewise, how a politician and a da'i speak, this has shown a link between language and culture.

Many previous studies have explored the relationship between language and culture, Kadri Krasniqi (Krasniqi, 2019) investigated the Relation between Language and Culture (Case Study Albanian Language) the results showed that characteristics of the Albanian language and culture, and other significant references results that language, apart from being a mirror that reflects a culture, behavior and management of the Albanian people in general, it also deals with the sounds, symbols and gestures that a nation, a tribe or a community uses as a 
means of communication. But if we go to a deeper level, language is also an expression of who we are as individuals, as communities or even as nations. Whereas, culture refers to dynamic social systems and shared patterns of behavior, beliefs, knowledge, attitudes and values and above all, provides the environment in which language develops, even as it influences how these issues are used and interpreted. Another study is promoted by David elmes (Elmes, 2013), this paper introduces the concepts of language and culture, and explores the viability of their relationship based on the three possible relationships proposed by Wardhaugh (i.e. the structure of the language determines the way we use language, cultural values determine language usage, and the neutral claim that a relationship does not exist). The importance of cultural competency is then considered for its importance to language education and the implications it holds for language learning and policy.

So the relationship between language and culture according to the definition above is very clear, namely that language is the first culture possessed by every human being; language can develop because of the developing mind and human knowledge system. Generally, there are two languages that come from our own culture, namely; ethnic (regional) language and Indonesian. Ethnic languages are more dominant in rural areas and Indonesian is more dominant in cities. This ethnic language is starting to become extinct, because users should have stated to leave or not use their ethnic language, so many people can no longer speak according to their ethnicity.

Mandailing is a traditional cultural group mainly living in the northern section of Sumatera Island, Indonesia. It is divided into 2 (two) major regions, namely Mandailing Godang (Mandailing Besar; living around agricultural areas and Mandailing Julu/Ulu (Mandailing Hulu/Kecil); living around plantation areas.(Silalahi, Roswita. Nasution, Ely Hayati., \& Harahap, 2017). Padangsidimpuan area which is a native speaker of the Angkola- Mandailing language which is now starting to decrease or become extinct due to generations. Young generations have not been taught to speak Angkola- Mandailing, but rather parents encourage their children to communicate in Indonesian so that the younger generation along with the loss of ethnic languages as well as the culture in Padangsidimpuan.

Based on the explanation above, it is clear that the problems that arise in the community, especially the Padangsidimpuan community. Therefore, this study will discuss the importance of language as $\mathrm{s}$ tool or means of culture.

\section{Literature review}


Nababan (Nababan, 1986) states that each language has four groups of functions, namely; Social functions, individual functions, educational functions and culture functions. The function of language in the culture especially in the Angkola community, which can be further divided into three functions, namely: (1) Language as a means of cultural development, (2) Language as a cultural heir pathway, (3) Language as an inventory of cultural features.

\section{Language as a means of cultural development}

Cultural development is a process of enhancing or maintaining existing habits in society in societal development studies that describe how culture and society change over time which is widely shown as a global influence. Cultural development is broadly developed through transnational interests. All forms of pleasure are involved in this cultural development effort to face cultural globalization, it is very difficult for people to preserve their own local culture which is the uniqueness of their region, but this cultural globalization is an important component in the development of their own regional communities. In the context of community development, cultural development has four components, namely:

\section{Preserving and respecting local culture}

Local cultural traditions are an important part of instilling a sense of community, and helping to give them a sense of identity. Therefore community development will seek to identify important elements of local culture and preserve them. These traditions include local history and valuable relics, locally based crafts, local food or anything else external influences can separate these local cultural traditions, and careful community strategy is required if these traditions are to be preserved. Communities need to identify what are the unique and significant components of their cultural heritage, and to determine which components to preserve. Therefore, a plan can be drawn up on how to achieve this, for example activities in community centers, building local industries based on local culture.

\section{Preserving and respecting native or indigenous culture}

When it is argued that indigenous culture is only a specific case in local culture, the different dynamics surrounding indigenous culture mean that this indigenous culture is treated as a separate thing. There are two main things that underlie it, namely, firstly the special claims that indigenous people have to land or areas and to traditional community structures that developed as hard as the land or area over a period of time much longer than the new colonization. Community is important for cultural continuity and spiritual continuity, in the important sense that traditional cultural preservation is a more important need for indigenous people than most other people. 


\section{Multiculturalism}

This word usually refers to different ethnic groups living in one society but maintaining different cultural identities. Hence, this focus is on the ethnicity and cultural features of different ethnic groups. Habits in a relatively homogeneous culture seem lost; society must arrive at a multicultural social life. For some, this occurs because of fear, threat, loss and raisal as well as cultural tension and exclusion. The diversity of cultural backgrounds is a reality for many societies, and therefore an important aspect of community development. The clash of cultural values and problems experienced by individuals and families provides an atmosphere of instability and anxiety as they try to find a way through this conflict. The strategies used in situations of multiculturalism include working with community leaders, raising awareness of the population, and dealing with racism.

\section{Participatory culture}

Cultural activities are an important focus for community identity, participation, social interaction and community development. One way to encourage a healthy society is to encourage broad participation in cultural activities, so that art, music, theater, dance and sport become something they do, not what they watch. This has been the focus of many community cultural development programs; Cultural participation can be seen as an important means of building social capital, strengthening communities and affirming identity. The activities that may be carried out will vary depending on local culture, local culture and other factors. A participative culture also has the potential to do more than strengthen social capital and community building. Participation in cultural activities is an important part of helping people from a society to regain their own culture and refuse to interfere with those outside them.

\section{Language as a path of heir or cultural inheritance}

Cultural inheritance is a process, acts or way of inheriting the culture of the community. The process of cultural inheritance is carried out by the community towards community members throughout the life of the community members. From birth to the end of life. The purpose of cultural inheritance is to shape the attitudes and behavior of citizens in accordance with the culture of the community. Culture is passed from previous generations to the next. Henceforth passed on to future generations. Cultural inheritance in the family occurs naturally and naturally. When the family jokes together in the family room, in fact, without realizing it, cultural inheritance is happening. When the family is eating together while talking, actually cultural inheritance is happening. When the family is having a recreation to a place, actually there is a family inheritance. When parents give advice, give punishment, and give praise and gifts, is one way of passing on culture. Cultural inheritance in the family occur every day using 
language. The process of cultural inheritance in the Angkola community is by telling folk stories; myths, legends and fairy tales. This way of cultural inheritance in the Angkola community usually occurs simply, namely through face to face, word of mouth and direct practice. People with the hunting type inherit their hunting skills by bringing their children directly to participate in hunting

\section{Language as an inventory of cultural features}

Cultural inventory is the writing of culture both in books and in research results. Such an inventory will be very useful, especially for future generations and for other people who want to know a culture. In this writing effort, the role of language is very important.

\section{Methods}

\section{Research design}

This research uses the basis of linguistics. Descriptively, this research is carried out solely based on the existing facts or phenomena that are empirically alive in the speakers. The data were obtained directly from informants by provoking answers based on a number of questions that had been compiled. Informants are selected according to predetermined criteria. In addition, data is also retrieved through documents.

\section{Data collection instruments}

The data was collected using the listening method and proficient method. Researchers directly visited the research site to collect data (Francis, 1983) (Sudaryanto, 1993). By applying this method, researchers can listen, pay attention, take notes, and collect other information that is not included in the list of questions. This information is expected to complement the research material. In addition, the researcher also observed the customs and socio-culture of the people in the research area. Data collection was also carried out by directly asking informants based on the required data.

\section{Data analysis}

The method used in data analysis is the equivalent method, especially the intralingual matching method (Mahsun, 2005). What is meant by the intralingual equivalent method is a method of analyzing data by way of connecting lingual elements, both those found in one language or in several different languages. The results of this study will then be presented in the form of a descriptive description.

\section{Results dan discussions}




\section{Analysis of relationship between language applications and culture;}

\section{Angkola-Mandailing community}

This research only examines the function of language in the culture of the Angkola community, which can be further divided into three functions, namely: (1) Language as a means of cultural development, (2) Language as a cultural heir pathway, (3) Language as an inventory of cultural features.

Based on data analysis, the results of Languages as a means of cultural development of the Angkola community are;

1. Maulid Nabi (the birthday of the Prophet) is one example in the Angkola community that developed its culture. This culture is always carried out on the day so it is clear that the culture of the Angkola people is seen, like eating together.

2. Israj mi'raj is one example in the Angkola community who developed its culture. Same is the case with the prophet's birthday warning above.

3. Margondang boru, is another example that exists in the Angkola community which develops its culture.

4. Mangayun, another example that exists in the Angkola community that develops its culture

Languages as a path of heir or cultural inheritance in Angkola society are:

1. Makkobar language is an example of the language as a successor to the Angkola culture which still exists today

2. The language of martahi / marpege-pege that still exists today, which is done before the wedding ceremony

3. The language of Mandohoni (delivering a celebration event without an invitation) mandohoni still exists today in the Angkola community even though it is not like it used to be directly met, now it is by telephone but is still called mandohoni

4. The language of mangguari (giving names to babies) which still exists today, which is practiced by the Angkola community.

5. The language of mangaligi na menek (a woman's grandmother's visit to see her first grandchild) that still exists today, is practiced by the Angkola community, even if it is not done by this woman's grandmother, the myth is that her grandson is not healthy

6. The language of mebat (the day the bride returns to her mother's house) mebat is still around today, which is practiced by the Angkola community, even if it is not done, it is forbidden for the bride to come to her mother's house before the mebat

7. The language of marhata- hata (makkobar) (sungkeman during Eid) marhata- hata is still around today, is practiced by the Angkola community, and must be done before the Eid al-Fitr prayer. 
8. Mangalomang (cooking lemang) is still around today, which is done by the the Angkola community during the last fasting of Ramadhan.

Languages as an inventory of cultural features or cultural characteristics in Angkola society are

1. Hudon tano (priuk from the terracotta) can no longer be found, but the community knows what hudon tano is.

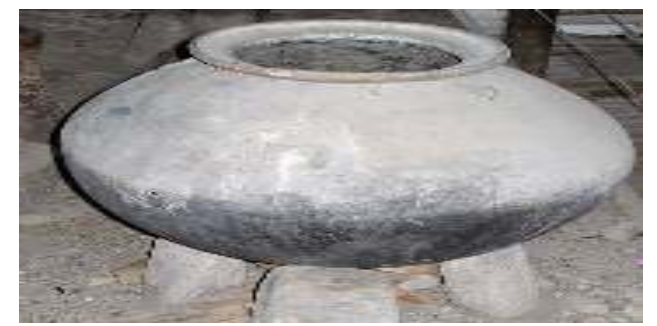

Figure 1 (unknown, 2019)

2. Losung batu (stone mortar) is no longer found, but the community knows what losung batu is.

3. Tumbilang (a tool for digging) no more objects were found, but people know what tumbilang is.

4. Harimotting (a type of small fruit in the forest) is no longer found, but people know what harimotting is.

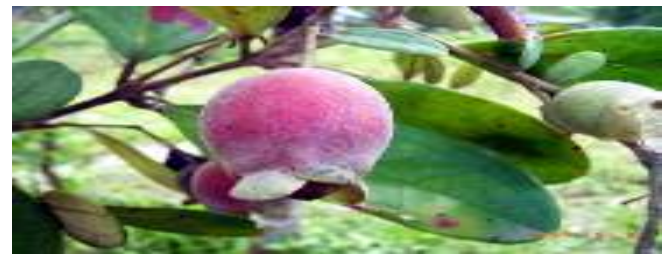

Figure 2 (Pakpahan, 2013)

5. Ceret- ceret (a type of plant shaped like a teapot) were no longer found, but the people knew what kettles were.

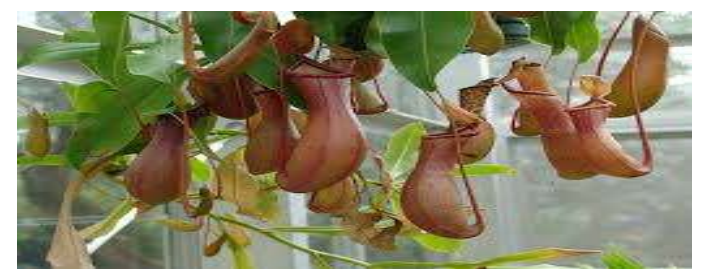

Figure 3 (Marpaung, 2020)

6. Hapadan (a small fruit found in the forest) was no longer found, but the community knows what hapadan is.

7. Kantil (a type of rantang) is no longer found, but people know what kantil is 
8. Dopang-dopang (a type of children's toy made of bamboo) was no longer found but the community knows what dopang-dopang

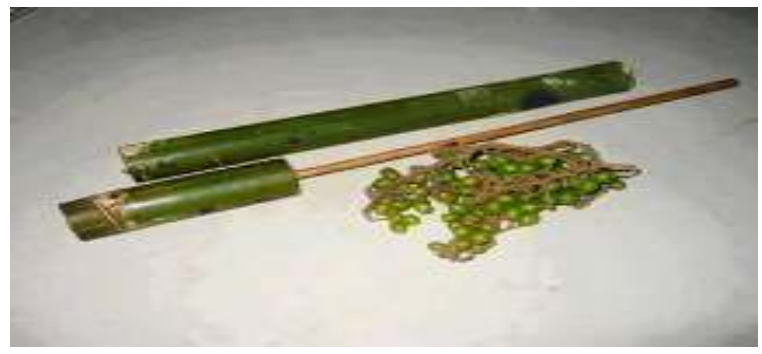

Figure 4 (Hendrika, 2015)

9. Gajambang (a type of plant that floats in a fish pond) is no longer found but the people know what Gajambang is

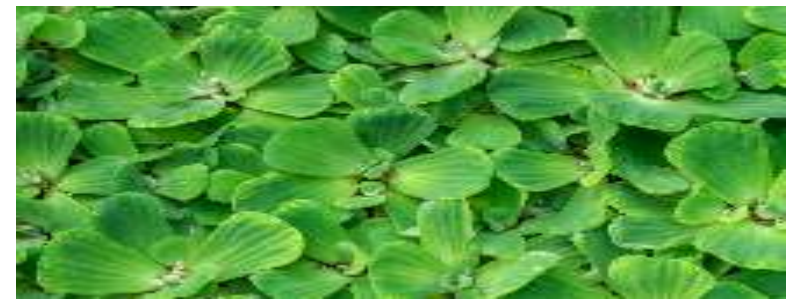

Figure 5 (Rossa, 2019)

10. Limatok (a type of leech that is found in rice fields when winter) is no longer found but the people know what limatok is

11. Markusip (the way people used to date / whisper) no one else does that, but people know how it is markusip.

12. Marsialap ari (mutual cooperation carried out by the angkola community) is no longer doing this, but the community knows how it is

13. Manakko dalan (the first day the baby is brought out) no one else does that, but people know how it is manakko dalan.

\section{Conclusions and suggestions}

The relationship between language and culture is very clear in this study, because without language it is culture, and culture includes language. In the above explanation, several examples of language and cultural relations have been clarified again with language as the cultural developer of the Angkola community, for example: margondang. Language is the successor or cultural heir of the Angkola community, for example: martahi / marpege-pege which is still inherited today by the Angkola community. And language as an inventory of the culture of the Angkola community, for example: markusip which is no longer practiced by young people in Padangsidimpuan, however, the Angkola community knows what markusip is. The reseracher suggests to the next other researchers to 
analyze more deeply about the relationship between language application and culture to another community in Indonesia.

\section{References}

Barber, C. . (1964). The Story of Language. The Chaucer Press.

Chaer, A. (1995). Sosiolinguistik Perkenalan Awal. Rineka Cipta.

Dardjowidjojo, S. (2003). Psikolinguistik: Pengantar Pemahaman Bahasa Manusia. Yayasan Obor.

Darsita. (2003). Hubungan antara Bahasa dan Kebudayaan menurut Cara Pandang Strukturalisme Levi Strauss. Al Turats, 9(2), 135.

Elmes, david. (2013). The Relationship between Language and Culture. *鹿屋 体育大学国際交流センター National Institute of Fitness and Sports in Kanoya International Exchange and Language Education Center, 46. http://www.lib.nifs-k.ac.jp/nii/46-11.pdf

Francis, W. N. (1983). Dialectology: An Introduction. Longman.

Hassamudin, Z. (2001). selain bahasa sebagai unsur utama kebudayaan, masih ada unsur penting lainnya yang merupakan penyimbulan dari beberapa budaya seperti ekspresi seni, agama dll. Al Lughah, 58-59.

Hendrika, E. (2015). Peletokan Bambu Mainan Anak Nusantara. Wordpress.Com.

https://erikhendrika.wordpress.com/2015/o3/o3/peletokan-bambumainan-anak-nusantara/

Herman. (2009). Bahasa Mempengaruhi Budaya? Tunggu Dulu. Id.Acehinstite.Otg.

Keraf, G. (1984). Komposisi. Nusa Indah.

Koentjaraningrat. (1992). Kebudayaan, mentalitas dan pembangunan. Gramedia Pustaka Utama.

Krasniqi, kadri. (2019). The Relation between Language and Culture (Case Study Albanian Language). Linguistics and Literature Studies, 7, 71-74. https://doi.org/DOI: 10.13189/lls.2019.070205

Kridalaksana, H. (2008). Kamus Linguistik. In keempat (p. 254). PT Gramedia Pustaka Utama Jakarta.

Mahsun. (2005). Metode Penelitian Bahasa. Raja Grafindo Persada.

Marpaung, A. (2020). Tanaman Karnivora: Cara Perawatan si Pelahap Serangga.

McLuhan, M. (1964). Understanding Media: The Extensions of Man. The MIT 
Press.

Nababan. (1986). Sosiolinguistik Suatu Pengantar. Gramedia Pustaka Utama.

Pakpahan, P. (2013). Lau-lau Harimotting. http://pahotpakpahan.blogspot.com/2013/04/lau-lau-harimotting.html

Rossa, V. (2019). Selain Cantik, 5 Tanaman Ini Jago Membersihkan Kolam Ikan di Rumah. Suara.Com. https://www.suara.com/lifestyle/2019/o8/16/165435/selain-cantik-5tanaman-ini-jago-membersihkan-kolam-ikan-di-rumah?page=all

Samsuri. (1974). Analisa Bahasa; Memahami Bahasa Secara Ilmiah. Erlangga.

Sapir, W. (1921). Language. Harc curt, Brace and World Inc.

Sibarani, R. (1992). Hakikat Bahasa. Citra Adtya Bakti.

Sibarani, R. (2004). Antropolinguistik (Antropologi Linguistik, Linguistik Antropologi). Poda.

Silalahi, Roswita. Nasution, Ely Hayati., \& Harahap, A. L. (2017). Onang-onang: Angkola Mandailing Oral Tradition (Viewed from Culture, Local Wisdom and Education Perspectives). Proceedings of the 2nd International Conference on Social and Political Development (ICOSOP 2017), 115-120. https://doi.org/https://dx.doi.org/10.2991/icosop-17.2018.18

Sudaryanto. (1993). Metode dan Aneka Teknik Analisis Bahasa. Duta Wacana University Press.

Thohiry. (2017). aspek bahasa dan budaya dalam pengajaran bahasa arab. Wordpress.

unknown. (2019). Dalihan na tolu dalam adat bangso batak. https://jsmmanaluer7.blogspot.com/2016/05/dalihan-na-tolu-dalamadat-bangso-batak.html 